\title{
Państwo i reguły zarządzania instytucjami publicznymi oraz majątkiem skarbu państwa po 2015 roku
}

\begin{abstract}
Streszczenie
Autorka na podstawie danych empirycznych uzasadnia tezę, że merytokratyczne podejście do metod rządzenia w państwie jest w Polsce słabo zakorzenione ${ }^{2}$. Wskazuje, że w instytucjach zależnych od rządu oraz spółkach skarbu państwa w okresie od połowy listopada 2015 r. do początku listopada 2017 r. doszło do całkowitego zarzucenia tych metod. Większość niezwykle licznie uchwalanych ustaw skupiała się na szybkości i szerokiej wymianie ciał zarządzających kluczowymi instytucjami i spółkami. Na dalszym planie pozostawała zwykle poprawa efektywności działania tych podmiotów. W wielu przypadkach głównym kryterium awansu było zaufanie decydenta.

Najważniejszym skutkiem społecznym prowadzenia nieprzejrzystej, nieopartej na merytorycznych zasadach polityki personalnej jest podważanie zaufania do państwa, co jest degradujące zarówno dla klasy politycznej, jak i dla ogółu obywateli.
\end{abstract}

\section{The state and governance in public institutions including state-owned companies after 2015}

\begin{abstract}
The author - using empirical data - claims that a meritocratic approach to public governance in Poland does not seem deeply rooted. The research indicates that since mid-November 2015 until the beginning of November 2017 meritocratic rules have been totally ignored in governmental institutions including state-owned companies.

1 Ekspert forumIdei w Fundacji im. Stefana Batorego.

2 Artykuł powstał na podstawie opracowania G. Kopińska, Stanowiska publiczne jako łup polityczny, http://www.batory.org.pl/publikacje/artykuly_17/przeciw_korupcji_1, przygotowanego w ramach prac forumIdei Fundacji im. Stefana Batorego (http://www.batory.org.pl/forum_idei/o_forum).
\end{abstract}


Many legal regulations were enacted in order to introduce changes in managing bodies responsible for key public institutions as well as companies. The drive to improve their effectiveness were not of prime importance. The key criterion for promoting was based on the decision-maker's personal trust. There are many implications of the above-mentioned development, including a loss of trust to the state resulting in a moral degeneration from the perspective of political class as well society as a whole.

Keywords: public governance, meritocracy, economy, business, nation state

Współczesne dyskusje o państwie często dotykają problematyki zarządzania zasobami państwa. Chodzi o zasoby najbardziej oczywiste, jakim jest administracja publiczna, ale także o zasoby materialne czy biznesowe, które znajdują się pod kontrolą różnych instytucji państwa. Powraca również kwestia, do jakiego poziomu zarządzanie może być oparte na zasadach merytokratycznych oraz do jakiego stopnia może podlegać upolitycznieniu. Istnieje tu także dodatkowa kwestia - nominacje polityczne nie muszą oznaczać nominacji osób, które są niekompetentne, a ich działanie nie musi z konieczności przynosić wymiernych strat. Niemniej współcześnie widoczne jest to, że zakres bezpośredniej władzy klasy polityków w krajach najwyżej rozwiniętych raczej się kurczy. Rośnie liczba instytucji publicznych, których legitymizacja pochodzi ze źródeł merytokratycznych, czyli zdolności do zapewnienia dobrych dla społeczeństwa rezultatów z uwagi na zdolność do oparcia działań na zobiektywizowanej wiedzy, na profesjonalizmie.

M. Kwiatkowski, za W. Wesołowskim, pojęcie merytokracji określa jako „system społeczno-polityczny (wyłaniający się bądź istniejący realnie), w którym kierowanie sprawami życia publicznego jest złożone w ręce ludzi najlepiej do tego przygotowanych, kompetencje są podstawą pełnienia ważnych ról społecznych, za pełnienie których należą się wysokie nagrody”. Dodaje, że w polskiej socjologii badania nad merytokracją mają bogatą tradycję (Kwiatkowski, 2017: 209).

Merytokratyczny model zarządzania państwem opiera się na pewnych założeniach. Są to zestawy reguł oraz nadrzędność kompetencji w decyzjach dotyczących awansu w administracji publicznej oraz w sferze państwowego biznesu. Choć ma on krytyków podnoszących takie jego ograniczenia jak podatność na egalitaryzm, replikowanie się elit rządzących czy tylko pozorne otwarcie drogi awansu, to trudno nie przyznać, że w drugiej połowie XX w. większość krajów demokratycznych budowała lub przynajmniej deklarowała chęć tworzenia systemu zarządzania państwem opartego na zasadach merytokratycznych. Sytuację w krajach nordyckich, przede wszystkim w Szwecji, A. Dziedziczak-Foltyn i K. Musiał opisują w następujący sposób: „Na północy Europy orientacja na dobre rządzenie możliwa była dzięki 
wszechobecnemu dyskursowi racjonalności powiązanemu z merytokracją. Uznanie prymatu merytokracji w sferze publicznej wytworzyło swoistą symbiozę pomiędzy korporatywizmem, silnym sektorem państwowym a ruchami społecznymi i partiami politycznymi. (...) Merytokracja dawała poczucie równości szans i oparcia o racjonalne kryteria sposobów awansu zawodowego i społecznego" (Dziedziczak-Fołtyn, Musiał, 2015: 28-29). Natomiast w Holandii wyłanianie kandydatów do pracy w instytucjach publicznych odbywa się w drodze otwartego konkursu, który prowadzony jest przez zewnętrzne, niezależne od administracji firmy prywatne typu headhunterskiego. I choć nie ma jednej określonej przez administrację procedury, to badacze oceniają, że „biurokracja holenderska charakteryzuje się polityczną neutralnością i technokratyczną specjalizacją" (Wojnarska-Krajewska, 2006).

Nie ma w tym nic zaskakującego, że państwa Europy Środkowo-Wschodniej po upadku bloku radzieckiego deklarowały wprowadzenie zasad merytokracji w zarządzaniu państwem wraz z tym, gdy rozpoczęły budowę państwa opartego na modelu zachodnim (Jasiecki, 2016). Znaczna część literatury przedmiotu wskazuje, że próby te nie do końca były udane (Jasiecki, 2013; Dziedziczak-Foltyn, Musiał, 2015). Trudno nie zgodzić się z opiniami wielu badaczy, patrząc na to, w jaki sposób klasa polityczna po 1989 r. zarządzała naszym państwem, zwłaszcza administracją publiczną i spółkami skarbu państwa. Służba cywilna podlegała stałej rotacji następującej wraz z cyklem wyborczym (Gadowska, 2015), w rezultacie czego jest zależna od polityków i nie jest dla nich partnerem w dziedzinie zarządzania państwem (Zybała, 2017).

W Polsce, ale również w innych krajach dawnego bloku wschodniego, merytokratyzm traktowany jest często jako postulat normatywny czy zasady, których nie praktykowano pomimo teoretycznego uznania dla nich (Zybała, 2017). Jako przyczyny takiego stanu rzeczy wymienia się m.in. zawłaszczenie państwa przez partie polityczne, słabość rządów prawa, kryzys dialogu społecznego czy niską kulturę polityczną społeczeństwa (Jasiecki, 2016).

Warto przywołać tu także termin „zawłaszczenie państwa”, który dobrze opisuje zjawiska widoczne w Polsce, jak i w naszym regionie. Tradycyjnie się przyjęło, że odnosi się on przede wszystkim do sytuacji, w której jakaś grupa interesu, zewnętrzna w stosunku do rządzących, kupuje sobie decyzje, które przynoszą jej korzyści przede wszystkim finansowe. Kilka lat temu $Ł$. Afeltowicz definiował zawłaszczenie państwa: „SC [state capture] dotyczy kształtowania praw i reguł obowiązujących uczestników gry rynkowej poprzez wypaczenie czy też »podkopanie « zasad funkcjonowania instytucji, w efekcie czego wąska grupa aktorów zyskuje uprzywilejowaną pozycję, przynosząc jednak straty społeczeństwu jako całości” (Afeltowicz, 2010). Wydaje się jednak, że obecnie, zwłaszcza w dyskursie publicznym, coraz częściej używa się tego pojęcia w szerszym znaczeniu. Zawłaszczyć państwo może grupa polityczna, która 
zmieniając reguły prawa, obsadza nie tylko kluczowe, ale niemal wszystkie znaczące instytucje państwa.

Poniżej staram się uzasadnić tezę dotyczącą reguł zarządzania publicznego po przejęciu władzy przez Zjednoczoną Prawicę. Materiał empiryczny pozwala na postawienie tezy, że po 2015 r. nastąpiła zmiana nie tylko ilościowa, ale i jakościowa w sposobie zarządzania państwem. Wydaje się, że zasady merytokratyczne w jeszcze większym stopniu niż wcześniej nie są honorowane.

W analizach opieram się na podejściu instytucjonalnym zakładającym kluczową rolę dla instytucji w dynamice rozwoju sytuacji społeczno-ekonomicznej. Odwołuję się do danych empirycznych pochodzących z różnych źródeł, zazwyczaj pokazujących skalę zmian w instytucjach publicznych i podmiotach biznesowych kontrolowanych przez rząd. Zebrane dane wskazują, że na stanowiska publiczne i do ciał zarządczych instytucji zależnych od skarbu państwa powoływane są osoby, które nie posiadają właściwego przygotowania fachowego i doświadczenia. Usprawiedliwiane jest to koniecznością realizacji obietnic wyborczych składanych suwerenowi przez kandydatów na parlamentarzystów z partii rządzącej.

Trzeba podkreślić, że wymiana kadry zarządzającej administracją publiczną czy firmami państwowymi po zmianie rządu nie jest zjawiskiem nieznanym wcześniej ani szczególnie charakterystycznym dla polskich realiów (Gadowska, 2017; Burnetko, 2003; Kwiatkowski, 2017). Po 1989 r. społeczeństwo przyzwyczaiło się do tego, że każdy nowo powołany rząd przeprowadzał zmiany personalne $\mathrm{w}$ administracji państwowej i podległych mu spółkach. Szybkość, głębokość i sposób wprowadzania tych zmian były różne, ale przynamniej od 20 lat każdorazowo wzbudzały zainteresowanie i często krytykę środowisk opiniotwórczych, mediów oraz opinii publicznej. Mówiono o kumoterstwie, klientelizmie politycznym czy zawłaszczaniu państwa. M. Kwiatkowski pisze o „syndromie gier kadrowych” w kontekście obsadzania stanowisk publicznych i zastosowania kryteriów merytorycznych. Wskazuje, przywołując również swoje wcześniejsze prace, na partykularyzm grupowy widoczny wśród polityków, a w odniesieniu do stosowania reguł merytokratycznych „przeświadczenie o przewadze nieoficjalnych reguł pozamerytorycznych nad oficjalnie deklarowanymi” (Kwiatkowski, 2017: 210). Socjolodzy wyjaśniają to zjawisko głównie specyficznym charakterem polskiego kapitału społecznego, w którym zaufanie występuje tylko w wąskich kręgach.

Ciekawe jest to, że obóz polityczny obecnie sprawujący władzę, nim sięgnął po rządy, formułował ambitne cele. Deklarował walkę z upartyjnianiem państwa, odpolitycznienie administracji, zapowiadał wprowadzenie jasnego i transparentnego naboru do służby cywilnej, a nawet likwidację gabinetów politycznych (Kwiatkowski, 2017: 211-212). Stąd, jak pisze M. Kwiatkowski, można mówić o zaskoczeniu 
zarówno charakterem, sposobem, jak i tempem wprowadzania zmian. „Wymownym tego przejawem jest rekordowa liczba ustaw uchwalonych w ciągu pierwszych stu dni rządów. Zjawisko to trafnie zostało nazwane "huraganem legislacyjnym "” (Kwiatkowski, 2017: 213).

\section{Charakterystyka zmian wprowadzanych po wyborach 2015 roku}

Obóz Zjednoczonej Prawicy w sferze zarządzania publicznego przez pierwsze dwa lata rządów położył największy nacisk na wymianę kadr. Jeśli zmieniano podstawy prawne działania służby cywilnej, prokuratury czy instytutów badawczych, to priorytet dawano takim rozwiązaniom, które umożliwiały przede wszystkim szybką wymianę kadr. Zmiany instytucjonalne, które miałyby służyć lepszemu sformułowaniu celów czy sposobu działania tych instytucji, rzadko bywały przedmiotem zainteresowania. Stan ten M. Kwiatkowski ocenia jako zagrożenie „dobra publicznego ze względu na realizację partykularnych interesów partyjnych lub frakcyjnych" (Kwiatkowski, 2017: 224).

Po przeanalizowaniu kilkudziesięciu przykładów wymiany kadr w okresie od połowy listopada 2015 r. do listopada 2017 r. dochodzę do wniosku, że to, co różni sposób, w jaki przejmowano instytucje publiczne i spółki zależne od skarbu państwa za poprzednich rządów i za rządu premier Beaty Szydło, to przede wszystkim szybkość, szerokość, głębokość, ale też charakter przeprowadzanych zmian personalnych.

\section{Tempo zmian}

O szybkości przeprowadzonych zmian świadczy np. fakt, że w mniej niż pół roku wymieniono osoby zajmujące kierownicze stanowiska w administracji publicznej, służbie cywilnej, a także prezesów największych spółek. Dziennikarze „Rzeczpospolitej" (Tylko prezes..., 2016) ${ }^{3}$ sprawdzili, jak szybko wymieniano prezesów w 32 największych spółkach skarbu państwa. Wyliczyli, że poprzednie cztery rządy (wliczając w to pierwszy rząd PiS) w pierwszym półroczu wymieniły około 50 proc. prezesów. Rząd Beaty Szydło w pięć miesięcy wymienił wszystkich prezesów z wyjątkiem jednego - szefa PKO BP.

3 Rząd SLD (2002-2005) w pierwszym półroczu swoich rządów wymienił nieco ponad połowę (55,5 proc.) prezesów tych spółek; pierwszy rząd PiS (2005-2007) - 46,6 proc., pierwszy rząd PO (20072011) - 56,3 proc., drugi rząd PO (2011-2015) - 20,3 proc. Natomiast obecny rząd PiS w 5 miesięcy wymienił 96,9 proc. prezesów spółek. 
Koalicji PO-PSL uzyskanie wpływu na sposób zarządzania mediami publicznymi zajęło prawie trzy lata. Latem 2010 r. po objęciu urzędu prezydenta przez Bronisława Komorowskiego sprawozdanie Krajowej Rady Radiofonii i Telewizji zostało skutecznie odrzucone, co otworzyło drogę do dokonania zmian w składzie Rady. Rząd PiS na całkowite podporządkowanie sobie KRRiT oraz wszystkich mediów publicznych i PAP potrzebował osiem i pół miesiąca. Rozpoczęto od uchwalenia 30 grudnia 2015 r. - w trybie poselskim - tzw. ustawy epizodycznej (Ustawa..., Dz. U. 2016, poz. 25). Na jej mocy kompetencje KRRiT polegające na prawie do wyboru zarządów i rad nadzorczych mediów publicznych na pół roku przejął minister skarbu. Jednocześnie zlikwidowano jawne i otwarte konkursy do władz mediów publicznych oraz ich kadencyjność. Dało to członkowi rządu możliwość swobodnego odwołania osób pełniących te funkcje w dowolnym momencie. Konsekwencją było powołanie 8 stycznia 2016 r. na stanowisko prezesa telewizji publicznej Jacka Kurskiego, polityka wielokrotnie sprawującego mandat posła, który od wyborów 2015 r. był wiceministrem w resorcie kultury.

Kolejnym krokiem było pozbawienie KRRiT odpowiedzialności za funkcjonowanie mediów publicznych. W czerwcu 2016 r. ponownie projektem poselskim znowelizowano dotychczasową ustawę (Ustawa..., Dz. U. 2016, poz. 929). Wprowadzono nową instytucję - Radę Mediów Narodowych, która przejęła nadzór nad mediami publicznymi. Jej główną kompetencją jest powoływanie i odwoływanie władz publicznego radia i telewizji oraz Polskiej Agencji Prasowej. Po wprowadzeniu tych zmian legislacyjnych można było przystąpić do wprowadzania zmian personalnych.

Najpierw (w lipcu 2016 r.) Parlament dokonał wyboru nowej Krajowej Rady Radiofonii i Telewizji. Spośród ośmiorga kandydatów zgłoszonych przez różne kluby parlamentarne wybrano trzech członków, wszyscy byli zgłoszeni przez Klub PiS. Prezydent w niejawnej procedurze wskazał kolejnych dwóch członków rady. Na przewodniczącego KRRiT wybrano Witolda Kołodziejskiego. Jest to członek Prawa i Sprawiedliwości, który przez kilka lat pełnił funkcję radnego różnych szczebli samorządu, a po wyborach 2015 r. był sekretarzem stanu w Ministerstwie Cyfryzacji. W latach 2007-2010 pełnił funkcję przewodniczącego KRRiT.

Również w lipcu 2016 r. powołano Radę Mediów Narodowych. Sejm wybrał dwie posłanki Prawa i Sprawiedliwości Elżbietę Kruk i Joannę Lichocką oraz sekretarza stanu w Ministerstwie Kultury i Dziedzictwa Narodowego Krzysztofa Czabańskiego. Tym razem prezydent wybierał dwóch członków spośród kandydatów zgłoszonych przez kluby opozycyjne Platformy Obywatelskiej i Kukiz'15. 2 sierpnia 2016 r. przewodniczącym Rady został Krzysztof Czabański. 


\section{Szerokość zmian}

Niemal równocześnie, w pierwszym roku rządzenia, wymieniono osoby pełniące wyższe stanowiska $\mathrm{w}$ administracji rządowej, obsadę prokuratur, prezesów sądów, zarządów i rad nadzorczych spółek skarbu państwa, wojewódzkich funduszy ochrony środowiska i gospodarki wodnej, kuratorów oświaty, a nawet dyrektorów oddziałów ZUS.

W raporcie Forum Obywatelskiego Rozwoju autorstwa J. Paczochy (2018) oszacowano, że ustawy przyjęte w pierwszych dwóch latach pracy Sejmu VIII kadencji „doprowadziły do zwolnienia co najmniej 11 tys. 368 stanowisk pracy, w tym ok. 6 tys. 773 stanowisk kierowniczych i członków organów wieloosobowych (m.in. zarządów i rad nadzorczych)".

\section{Charakter zmian}

Część zmian dotyczyła całych sektorów życia publicznego. Polegały one przede wszystkim na odstąpieniu od konkursowego naboru na kierownicze stanowiska i wprowadzeniu zatrudnienia na zasadzie powołań i odwołań, co skrajnie uzależnia zatrudnianych od posiadających moc zatrudniania i buduje stosunki klientelistyczne. Ponadto zmiany te połączone były z czasowym zawieszeniem nabytych praw pracowniczych, oznaczały bowiem wygaszenie wszystkich istniejących umów o pracę i brak ochrony prawnej dla zwalnianych pracowników. Pracodawca dostawał od 1 do 6 miesięcy na odnowienie lub zerwanie umów.

Z informacji uzyskanych z KPRM w trybie dostępu do informacji publicznych wynika, że w okresie przejściowym (od 23 stycznia do 22 lutego 2016 r.) (Ustawa..., Dz. U. 2016, poz. 34), czyli w ciągu jednego miesiąca, niemal jedna trzecia (505 z 1580 zatrudnionych w dniu 22.01.2016 r.) osób zatrudnionych na wyższych stanowiskach w służbie cywilnej zakończyło pracę lub zostało przeniesionych na inne stanowisko. Jeśli chodzi o cały 2016 rok, to $z$ danych opublikowanych w Sprawozdaniu Szefa Służby Cywilnej za 2016 r. wynika, że po raz pierwszy w historii spadła liczba urzędników mianowanych, o najwyższych kompetencjach, w stosunku do roku poprzedniego o 123 osoby (19 proc.). H. Izdebski ocenia, że „taka sytuacja to po części pokłosie nowelizacji ustawy o służbie cywilnej z grudnia 2015 r. Zlikwidowała konkurencyjny nabór na stanowiska kierownicze. Umożliwiła też usunięcie z wyższych stanowisk osób, które wcześniej je piastowały" (Wójcik, 2017).

Większość tych metod zastosowano: wobec osób zajmujących wyższe stanowiska w służbie cywilnej, przy powoływaniu Krajowej Administracji Skarbowej oraz Krajowego Ośrodka Wsparcia Rolnictwa, w trakcie zmian w prokuraturach, wojewódzkich 
funduszach ochrony środowiska i gospodarki wodnej czy przy zmianie sposobu obsadzania stanowisk dyrektorów, prezesów i wiceprezesów sądów oraz kuratorów oświaty. O zapisach ustawy Przepisy wprowadzające ustawę o Krajowej Administracji Skarbowej (Ustawa..., Dz. U. 2016, poz. 1948) A. Błaszczyńska, radca prawny z kancelarii Chałas i Wspólnicy, wyraziła się w następujący sposób: „art. 170 przepisów wprowadzających ustawę o KAS daje szefostwu nowej służby całkowicie arbitralne uprawnienia w zakresie dalszego zatrudniania czy proponowanych warunków pracy" (Fiskus i celnicy..., 2017).

\section{Sposoby dokonywania zmian personalnych}

Zmiany personalne polegały na zamienianiu ludzi, którzy zarządzali tymi instytucjami, na osoby znane rządzącym, do których rządzący mają zaufanie. W wielu przypadkach głównym kryterium awansu było zaufanie decydenta, a fachowość i doświadczenie pozostawały na dalszym planie.

Zarówno nominowanie czy zatrudnianie nowych „swoich”, jak i zwalnianie zastanych „obcych” odbywało się w podobny sposób. Przede wszystkim zmieniano obowiązujące prawo, ale wcale nierzadko, zwłaszcza bezpośrednio po przejęciu władzy, naruszano obowiązujące zasady prawa, obchodzono istniejące prawo, swobodnie je interpretując, lub wykorzystywano możliwości, jakie dają nieostre zapisy prawa.

\section{Przez szybką zmianę istniejącego prawa}

Aby móc wymienić kierownictwo Instytutu Wymiaru Sprawiedliwości, a nieco później wszystkich instytutów badawczych oraz m.in. Instytutu Pamięci Narodowej, Krajowej Rady Radiofonii i Telewizji, Fundacji Solidarności Międzynarodowej czy Centralnej Komisji do Spraw Stopni i Tytułów szybko, często projektami poselskimi, zmieniono obowiązujące ustawy.

Znamienny jest tu przykład sposobu, w jaki zmieniono ciała zarządcze w wojewódzkich funduszach ochrony środowiska i gospodarki wodnej (WFOŚiGW). Co roku fundusze te dysponują $8 \mathrm{mld}$ zł pochodzącymi przede wszystkim z funduszy unijnych i tzw. mechanizmu norweskiego. Przyznają dotacje i pożyczki częściowo umarzane jednostkom samorządu terytorialnego, przedsiębiorcom i osobom fizycznym. W 2010 r. funduszom tym nadano status samorządowych osób prawnych (Ustawa..., Dz. U. 2001, nr 62), co oznaczało, że znaczący wpływ na sposób rozdysponowania pokaźnych środków finansowych uzyskał samorząd wojewódzki. Rząd premier Beaty Szydło postanowił przejąć kontrolę nad funduszami. Posłowie Klubu Parlamentarnego 
Prawa i Sprawiedliwości wnieśli nowelizację Prawa Ochrony Środowiska (Projekt ustawy..., 2018).

$\mathrm{Z}$ dniem wejścia w życie noweli, 24 maja 2017 r., mandaty członków rad nadzorczych wszystkich WFOŚiGW zostały wygaszone. Zmniejszono ich liczbę kosztem m.in. samorządu województwa, z siedmiu do pięciu osób. Dotychczas w skład rad nadzorczych wchodzili dwaj przedstawiciele samorządu: przewodniczący lub zastępca przewodniczącego komisji do spraw środowiska sejmików województw oraz dyrektorzy albo wicedyrektorzy departamentów do spraw ochrony środowiska urzędów marszałkowskich. Obecnie jedynymi przedstawicielami samorządu w radach są ich wiceprzewodniczący wyznaczani przez sejmik województwa. Ze składu RN wykreślono przedstawicieli samorządów gospodarczych, a przedstawiciele organizacji pozarządowych są po nowelizacji wyznaczani przez wojewodę, a nie jak było poprzednio „zgłoszeni przez organizacje działające i posiadające struktury organizacyjne na terenie danego województwa i cieszący się poparciem największej liczby tych organizacji” (Ustawa..., Dz. U. 2001, nr 62)4.

Najważniejsza zmiana dotyczyła ciał mających uprawnienia powoływania i odwoływania rad nadzorczych WFOŚiGW. Po nowelizacji członków tych rad powołuje i odwołuje minister środowiska. Wcześniej pięciu z siedmiu członków rad powoływały i odwoływały, uwzględniając stanowiska organizacji ekologicznych i przedsiębiorców, sejmiki województw. Wszystkie te zmiany skutkowały tym, że rząd otrzymał znacznie większy wpływ na sposób przydzielania i wydatkowania funduszy przeznaczonych na ochronę środowiska w poszczególnych województwach.

$\mathrm{Z}$ analizy informacji dostępnych na stronach wojewódzkich funduszy wynika, że po wprowadzeniu w życie znowelizowanych zasad powoływania członków rad nadzorczych Wojewódzkich Funduszy Ochrony Środowiska i Gospodarki Wodnej wymieniono ponad 71 proc. ich dotychczasowego składu. Gdyby jednak wziąć pod uwagę fakt, że 10 członków rad co prawda było w poprzednich radach, ale znaleźli się tam dopiero po zmianie rządu - to odsetek wymienionych wzrośnie do prawie 84 proc. Wśród 13 członków rad nadzorczych mających staż dłuższy niż półtora roku są przede wszystkim (10 osób) przedstawiciele władzy samorządowej wyznaczeni przez marszałków województw. Tylko wojewoda małopolski, wskazując przedstawiciela nauki lub organizacji pozarządowych, skorzystał z osoby, która zasiadała poprzednio $\mathrm{w}$ radzie nadzorczej jako zgłoszona przez regionalne środowisko trzeciego sektora. Pozostali wskazali nowe osoby.

Rządowi udało się radykalnie wymienić składy rad nadzorczych WFOŚiGW, ale do października 2017 r. nie udało się zmienić zarządów funduszy. Stało się tak

\footnotetext{
$4 \quad$ Zgodnie z treścią art. $400 \mathrm{f}$ ust. 2 pkt 5.
} 
dlatego, że przed uchwaleniem nowelizacji ustawy sejmiki 15 spośród 16 województw, w których przewagę miały PO i PSL, zmieniły statuty WFOŚiGW. Zapisywano w nich, że zarządy funduszy muszą być wybierane przez rady nadzorcze jednomyślnie. Jak się spodziewano, wybory członków rad powoływanych przez władze samorządowe i ministerialne były odmienne.

Ponownie posłowie partii rządzącej postanowili „ratować sytuację”, gdyż jak powiedział poseł W. Skurkiewicz: „Chcieliśmy (...) doprecyzować przepisy tak, by jeśli sytuacja wymknie się spod kontroli czy przybierze nieoczekiwany obrót, mogli wkraczać wojewodowie. Zmiany władz WFOŚiGW są potrzebne, bo docierają do nas niepokojące informacje dotyczące rozdysponowania środków finansowych (...)" (Dryszel, 2017). 15 września 2017 r. uchwalili kolejną - zawierającą trzy artykuły mieszczące się na połowie strony - nowelizację Prawa Ochrony Środowiska (Projekt Ustawy..., 2017), która stanowi, że jeśli rada nadzorcza WFOŚiGW nie złoży do zarządu województwa wniosku o powołanie lub odwołanie zarządu funduszu, to wniosek taki, po uzgodnieniu go z ministrem środowiska, składa wojewoda. Jeśli zaś zarząd województwa w ciągu siedmiu dni nie powoła wskazanego we wniosku wojewody zarządu, to powoła go wojewoda.

Po kilku miesiącach 11 z 16 zarządów WFOŚiGW wymieniono w całości. W pozostałych pięciu pozostała jedna osoba ze starego składu zarządu.

Obie nowelizacje dotyczyły wyłącznie spraw personalnych. Nie wprowadzono żadnych zmian co do zakresu spraw, jakimi mają się zajmować wojewódzkie fundusze ochrony środowiska i gospodarki wodnej czy co do ich uprawnień. Zmiany dotyczyły wyłącznie składu i sposobu powoływania ciał zarządzających. W uzasadnieniach do projektów ustaw nie przeprowadzono jakiejkolwiek analizy istniejącej sytuacji, nie wykazano powodów, dla których należy dokonać zmian. Zapisano jedynie, że ich skutkiem będzie zmniejszenie kosztów działalności WFOŚiGW. Prawdopodobnie ma być to skutek zmniejszenia liczby członków rad nadzorczych.

\section{Z naruszeniem prawa}

Co najmniej w kilku przypadkach w trakcie dokonywania zmian we władzach spółek skarbu państwa naruszono przepisy obowiązującego prawa. Charakterystyczne jest też to, że niektóre osoby spośród tych, które właśnie w ten sposób zostały wprowadzone do zarządów lub rad nadzorczych firm zależnych od rządu, po kilku miesiącach straciły posady.

Za zgodne z prawem trudno uznać powołanie już w grudniu $2015 \mathrm{r}$. jednego z członków zarządu Polskiej Grupy Zbrojeniowej. Ta należąca do skarbu państwa firma skupia ponad 60 spółek głównie działających w branży obronnej, stoczniowej 
i nowych technologii, wśród nich takie, jak: Rosomak S.A., Fabryka Broni Łucznik z Radomia, Stocznia Remontowa Nauta czy Autosan S.A. Grupa osiąga roczne przychody na poziomie $5 \mathrm{mld}$ zł. Licząc z podwykonawcami, zatrudnia około 20 tys. pracowników. Poza Ministerstwem Skarbu Państwa udziałowcami są dwa państwowe podmioty: Agencja Rozwoju Przemysłu i Polski Holding Obronny.

Do 31 grudnia 2016 r. PGZ formalnie podlegała Ministerstwu Skarbu ${ }^{5}$. Jednak zaraz po utworzeniu rządu premier Beaty Szydło Ministerstwo Obrony Narodowej przejęło w imieniu skarbu państwa nadzór nad państwowymi spółkami zbrojeniowymi i postanowiło zmienić władze Polskiej Grupy Zbrojeniowej.

Zgodnie $\mathrm{z}$ wymogami zapisanymi w statucie PGZ członek zarządu powinien „posiadać wyższe wykształcenie oraz co najmniej pięcioletni staż pracy zgodny z zakresem obowiązków przewidzianym dla danej funkcji członka Zarządu” (Paragraf 19 Statutu PGZ).

9 grudnia 2015 r. Rada Nadzorcza PGZ odwołała dotychczasowy zarząd spółki i, jak podał PAP za komunikatem rzecznika MON, „powołała nowy, w skład którego weszli: 1. Arkadiusz Siwko - prezes zarządu, 2. Maciej Lew-Mirski - członek zarządu, 3. Radosław Obolewski - członek zarządu”. Wszyscy oni dłużej lub krócej współpracowali z ówczesnym ministrem obrony A. Macierewiczem ${ }^{6}$.

O ile nominacja dwu pierwszych członków zarządu nie budziła pod względem formalnym specjalnych zastrzeżeń, o tyle nie można tego powiedzieć o Radosławie Obolewskim. Jego wcześniejsze doświadczenia zawodowe nie były i nadal nie są publicznie znane. Wiadomo jedynie, że był szefem Klubu „Gazety Polskiej” w Łomiankach oraz według jednych źródeł - współwłaścicielem, a według innych - mężem właścicielki apteki „Aronia” w Łomiankach. Dziennikarze ustalili, że „w Krajowym Rejestrze Sądowym (...) pojawia się on przy okazji bycia skarbnikiem w Stowarzyszeniu Dobro Wspólne Łomianki” (Celej, 2015) oraz że bez powodzenia startował w wyborach samorządowych.

\footnotetext{
5 Do wejścia w życie ustawy z dnia 16 grudnia 2016 r. o zasadach zarządzania mieniem państwowym w zakresie nieuregulowanym w przepisach szczegółowych (Dz.U. 2016, poz. 2259); patrz też Ministrowie będa zarządzać 432 spółkami Skarbu Państwa, komunikat PAP, 3.01.2017.

6 W komunikacie PAP napisano: „Nowy prezes PGZ Arkadiusz Siwko to wieloletni współpracownik obecnego szefa MON Antoniego Macierewicza. Był m.in. szefem jego gabinetu, gdy Macierewicz kierował MSW (1991-1992), w latach 90. kierował redakcją „Głosu”, który Macierewicz wydawał. Za czasów poprzedniego rządu PiS Siwko był prezesem Naftobaz, przekształconych następnie w Operatora Logistycznego Paliw Płynnych (OLPP). To państwowa spółka, która ma w Polsce największe magazyny paliw. Maciej Lew-Mirski to były członek kierowanej przez Macierewicza komisji weryfikacyjnej Wojskowych Służb Informacyjnych. Razem z obecnym szefem MON współtworzył Służbę Kontrwywiadu Wojskowego. Z kolei Radosław Obolewski to szef Klubu »Gazety Polskiej« w Łomiankach”.
} 
Na podstawie upublicznionych informacji na temat doświadczenia zawodowego Radosława Obolewskiego z pewnością nie można stwierdzić, że spełnia on wymagania stawiane członkowi Zarządu PGZ.

Radosław Obolewski został odwołany z Zarządu PGZ po 10 miesiącach - prawdopodobnie 20 września $2016 \mathrm{r}$. Żadnej informacji o przyczynach tej decyzji, a nawet o samym fakcie, na stronach MON ani PGZ nie można odnaleźć.

\section{Swobodnie interpretując prawo}

W październiku 2016 r. premier odwołała prezesa Polskiej Agencji Kosmicznej, podając jako powód swojej decyzji nieprzyjęcie sprawozdań z działalności agencji w 2015 r. Jednocześnie na p.o. prezesa powołała wiceprezesa Agencji ds. Obronnych płk. Piotra Suszyńskiego 7 . Zgodnie z art. 22 ustawy o Polskiej Agencji Kosmicznej, mógł on pełnić tę funkcję najwyżej pół roku, a pełnił ją 17 miesięcy. Było to możliwe, gdyż co najmniej cztery organizowane przez KPRM konkursy pozostawały bez rozstrzygnięcia oraz gdyż, jak pisała „Rzeczpospolita” i co nigdzie nie zostało zdementowane: „W ostatnim dniu bycia p.o. prezesa płk Suszyński wydał zarządzenie o wyznaczeniu wiceprezesa ds. obronnych (czyli samego siebie) na osobę, która będzie zastępować prezesa »we wszystkich czynnościach o charakterze wykonawczym i zarządzającym»" (Ferfecki, 2017).

Na pytanie dziennikarza o podstawę wydania tego zarządzenia pracowniczka biura prasowego Agencji odpowiedziała, że „Zarządzenie to zostało wydane w oparciu o statut Polskiej Agencji Kosmicznej, jest więc zgodne z obowiązującymi przepisami prawa. Jego treść uzyskała akceptację KPRM, organu nadzorującego agencję z ramienia prezesa Rady Ministrów” (Ferfecki, 2017). Wydaje się, że jest to nawiązanie do art. 5 ust. 3 statutu Agencji, który brzmi: „Wiceprezes zastępujący Prezesa wykonuje zadania Prezesa podczas jego nieobecności lub czasowej niemożności wykonywania przez niego obowiązków”. Jednak skorzystanie z tego uprawnienia w ostatnim ustawowo możliwym dniu dla przedłużenia własnych uprawnień, wbrew zapisom ustawy - wydaje się mocno wątpliwe. Wątpliwości te ma również konstytucjonalista R. Balicki - „Wygląda to na obejście przepisów ustawy. Trudno stwierdzić, czy doszło do nadużycia prawnego, ale niewątpliwie ucierpiały standardy zarządzania instytucjami takiego typu" (Ferfecki, 2017).

7 Płk Piotr Suszyński p.o. Prezesa Polskiej Agencji Kosmicznej, komunikat b.d., Polska Agencja Kosmiczna https://polsa.gov.pl/wydarzenia/wydarzenia/13-ostatnie/172-plk-piotr-suszynski-p-o-prezesa-polskiej-agencji-kosmicznej, dostęp: 23.07.2018. 
Innym szeroko omawianym w mediach przykładem swobodnej interpretacji prawa był fakt powołania (12.06.2017 r.) na stanowiska członka zarządu PZU SA oraz PZU Życie SA Małgorzaty Sadurskiej. Ma ona poważny dorobek zawodowy, ale ściśle związany z jej aktywnością polityczną. Przez dziesięć lat była posłanką wybieraną z list PiS, a wcześniej, prawie przez trzy lata członkiem zarządu powiatu puławskiego ${ }^{8}$. We wrześniu 2007 r. została przez premiera Jarosława Kaczyńskiego powołana w skład Rady Nadzorczej III kadencji Zakładu Ubezpieczeń Społecznych jako reprezentant rządu, następnie objęła funkcję przewodniczącej rady. Od 7 sierpnia 2015 r. przez niemal dwa lata była Szefem Kancelarii Prezydenta Andrzeja Dudy.

Nominacja Małgorzaty Sadurskiej na członka zarządu największej w Polsce firmy ubezpieczeniowej ze względu na brak jej doświadczenia w zarządzaniu firmami biznesowymi wzbudziła wiele wątpliwości i komentarzy wśród polityków i dziennikarzy. Jednym z ustawowych (Ustawa..., Dz. U. 2016, poz. 2259) wymagań wobec członka zarządu spółek kontrolowanych przez skarb państwa jest posiadanie co najmniej trzyletniego doświadczenia na stanowiskach kierowniczych. W odpowiedzi na te zastrzeżenia Przewodniczący Stałego Komitetu Rady Ministrów Henryk Kowalczyk podczas obrad Sejmu (8.06.2017 r.) na pytanie o kwalifikacje kandydatki na członka zarządu PZU odpowiedział: „Jeśli np. zarządzanie, czyli bycie szefem Rady Nadzorczej ZUS, który wydaje $200 \mathrm{mld}$ zł rocznie, nie jest dobrym doświadczeniem, to nie wiem, jakie powinno być lepsze"

W tym samym czasie na kilku portalach ukazały się informacje (z powołaniem na komunikat PAP), że Małgorzata Sadurska „w latach 2007-2012 była też przewodniczącą Rady Nadzorczej ZUS” ${ }^{10}$. Ponieważ nie można było tych informacji potwierdzić na stronach ZUS, Fundacja Batorego wystąpiła do tej instytucji w trybie dostępu do informacji publicznej o przekazanie informacji na temat składu Rady Nadzorczej ZUS III kadencji. Z otrzymanej odpowiedzi wynika, że Małgorzata Sadurska zasiadała w Radzie Nadzorczej ZUS przez niepełne dwa miesiące - od 6 września do 2 listopada $2007 \mathrm{r}$.

Bycie przez trzy lata członkiem zarządu powiatu puławskiego oraz przez niemal dwa lata szefem Kancelarii Prezydenta RP prawdopodobnie można uznać za formalne spełnienie wymogu ustawowego wobec członka zarządu spółek kontrolowanych przez skarb państwa - posiadania co najmniej trzyletniego doświadczenia na stanowiskach

\footnotetext{
8 Kadencja nr IV (2002-2006) lista sesji, BIP Starostwo Powiatowe w Puławach, http://www.e-bip. $\mathrm{pl} /$ Start/62/Council/SessionsList/72, dostęp: 23.07.2018.

9 Wypowiedzi na posiedzeniach Sejmu, posiedzenie $\mathrm{nr} 43 \mathrm{w}$ dniu 8.06.2017, http://www.sejm.gov.pl/ sejm8.nsf/wypowiedz.xsp?posiedzenie=43\&dzien=2\&wyp=87\&symbol=INFO_WYP, dostęp 23.07.2018.

10 M.in. na Dziennik.pl., Newsweek.pl czy Money.pl
} 
kierowniczych. Ale czy faktycznie jest to doświadczenie, jakiego oczekiwalibyśmy od osoby współzarządzającej największą firmą ubezpieczeniową w kraju?

Na podstawie analizy tych i kilkudziesięciu innych przypadków zmian personalnych dokonanych za czasów rządu Beaty Szydło dochodzę do wniosku, że rządzący za podstawową zmianę w zarządzaniu państwem w pierwszym rzędzie uważają wymianę kadry zarządzającej, czasem nawet średniego szczebla. Zmiany instytucjonalne, które miałyby służyć lepszemu sformułowaniu celów czy sposobu działania tych instytucji, rzadko bywały przedmiotem ich zainteresowania.

\section{Skutki dokonywanych zmian}

Najważniejszym skutkiem społecznym prowadzenia nieprzejrzystej, nieopartej na merytorycznych zasadach polityki personalnej w zarządzaniu administracją, instytucjami publicznym i spółkami skarbu państwa jest podważanie zaufania do państwa. Jest to degradujące zarówno dla klasy politycznej, jak i dla ogółu obywateli. Osoby zainteresowane aktywnością polityczną otrzymują informację, że kluczem do ich kariery jest budowanie sieci powiązań i znajomości. O ich awansie życiowym i profesjonalnym nie będą decydowały fachowość, doświadczenie czy rzetelność, a lojalność względem patrona i spryt w pozbywaniu się konkurencji. Rodzi to bardzo szkodliwe postawy klientelistyczne (Zybertowicz, 2013, 114-123).

Działania te podważają również trwałość instytucji państwowych. Powodują brak ciągłości, zerwanie pamięci instytucjonalnej, zniszczenie kultury instytucji. Jeśli instytucja rzeczywiście źle działała, to tak drastyczne zmiany mogą mieć sens, ale w innych przypadkach jest to ryzykowne. Ciągłość instytucjonalna ważna jest dla tworzenia i utrzymywania właściwie działających struktur państwowych.

Wymiana kadr prowadzona zarówno przez poprzednie, jak i obecne rządy spełnia kilka funkcji. Jedną z nich jest danie satysfakcji i miejsc pracy własnemu zapleczu. Może to być rodzaj zapłaty za pracę w okresie kampanii wyborczej, za wierność i lojalność. Wymiana kadrowa, w przekonaniu dokonujących jej, ma także zapewnić lepszą realizację programu partii, zwłaszcza tzw. części ideowej, ma dać pewność, że będzie on realizowany we właściwy sposób.

Przeprowadzana od końca 2015 r. wymiana kadr może spełnić jeszcze jedną, jak sądzę chyba nie w pełni zamierzoną funkcję - dokonania częściowej wymiany pokoleniowej. Partia rządząca, która pozostawała przez osiem lat w opozycji, nie ma dostatecznie szerokiego zaplecza. Przeprowadzając szeroką i głęboką wymianę kadrową, siłą rzeczy musi sięgać po osoby spoza „establishmentu”, często osoby młode. 
W przywoływanej tu kilkakrotnie publikacji M. Kwiatkowski słusznie pisze, że w rewolucji kadrowej dominują reguły partykularne nad uniwersalnymi (dobro publiczne). „Pułapka partykularyzmu polega na tym, że próba rozwiązania bieżących problemów poprzez osłabienie znaczenia kryteriów merytorycznych zwiększa wpływ polityków na obsadzanie stanowisk oraz poszerza pole dla działań nieformalnych. Negatywne konsekwencje dotyczą nie tylko instytucji publicznych, ale także samej formacji rządzącej. Należy się spodziewać, że otwarcie politycznych ścieżek dostępu do stanowisk publicznych będzie windowało konformistów, wzmacniało podziały frakcyjne i budowało klientystyczne, antyreformatorskie sieci powiązań” (Kwiatkowski, 2017: 226). Kwiatkowski wskazuje również, że konsekwencje będą polegały na wzroście klientyzmu, obniżeniu wymogów profesjonalnych, otwieraniu ścieżki dostępu do publicznych stanowisk nominatom partyjnym. Wzmacniana będzie rola nieformalnych powiązań. Jest to ścieżka do osłabiania stabilności i sprawności instytucji publicznych.

Kwestią niezwykle istotną jest sprawa, na ile państwo w naszych warunkach można zabezpieczyć przed masową wymianą kadr po każdorazowej zmianie rządzących. Nie jest to proste, ale też jak wykazały prowadzone na ten temat dyskusje, brak jest jednoznacznego konsensusu wokół możliwych metod rozwiązania tego problemu. Pod rozwagę przedstawiam więc poniższe propozycje.

W dziedzinie administracji publicznej należałoby podjąć trud powrotu do idei profesjonalnej, lojalnej w stosunku do państwa administracji publicznej, która jest zbudowana na zasadach przestrzegania prawa i służenia dobru obywateli. Przyjęta w 1996 r. ustawa o służbie cywilnej wraz z wprowadzoną ustawą z 1998 r. zasadą obligatoryjnego, otwartego, jawnego i konkurencyjnego naboru do tej służby - dawały, niestety nigdy niewykorzystane prawidłowo, podstawy do zbudowania takiej właśnie formacji (Gadowska, 2018). Dlatego należałoby wrócić do zaproponowanych tam rozwiązań.

Stanowiska, które ulegają wymianie po zmianie rządów, czyli tzw. stanowiska polityczne, powinny być ustawowo określone i sięgać nie niżej niż stanowisk wiceministra i wojewody.

Konkursowy systemu naboru pracowników merytorycznych i zarządzających instytucjami publicznymi jest sposobem najwłaściwszym. Patologie, z którymi mieliśmy do czynienia w przeszłości, można wydatnie ograniczyć przez profesjonalizację i zwiększenie jawności naboru.

Służyłaby temu jawna i szeroko rozpowszechniana informacja o wolnych miejscach w służbie cywilnej i organizowanym naborze. Komisje kwalifikacyjne mogłyby być 
w połowie złożone z niezależnych profesjonalistów, a ich prace - otwarte na uczestniczenie w nich przedstawicieli związków zawodowych czy stowarzyszeń na zasadzie obserwatorów. Natomiast przy naborze na najwyższe stanowiska $w$ administracji publicznej należałoby organizować publiczne wysłuchania kandydatów otwarte dla wszystkich zainteresowanych. Po zakończeniu procedury naboru dokumentacja powinna być upubliczniana, $\mathrm{z}$ wyjątkiem danych podlegających ochronie.

Zdecydowanie trudniejsze jest zaproponowanie rozwiązań, które ograniczałyby upartyjnienie zarządzania spółkami skarbu państwa. Wynika to przede wszystkim z faktu, że zadaniem tych podmiotów jest realizowanie celów gospodarczych oraz w określonych sytuacjach celów społecznych. Biorąc pod uwagę fakt, że władze tych spółek zarządzają pieniędzmi publicznymi, należy przede wszystkim rozszerzyć zakres jawności oraz przedstawianych informacji o podejmowanych przez nie działaniach.

Pomocne w ograniczaniu zatrudniania osób nieposiadających stosownego przygotowania i umiejętności mogłoby być opracowanie dość szczegółowych wymagań w stosunku do kandydatów zarówno do rad nadzorczych, jak i zarządów spółek skarbu państwa. Sensowne wydaje się zróżnicowanie wymagań w zależności od wielkości spółki, jej majątku czy liczby zatrudnianych osób - im większa spółka, tym wyższe wymagania.

Kandydaci do rad nadzorczych, z wyjątkiem przedstawicieli załóg, powinni mieć przede wszystkim wykształcenie prawnicze lub ekonomiczne i doświadczenie w zarządzaniu instytucjami, w dużych firmach - co najmniej trzy lata.

W stosunku do kandydatów na członków zarządów powinno się przede wszystkim oceniać ich doświadczenie i osiągnięcia zawodowe. Liczyć się powinna nie tylko długość stażu na stanowiskach kierowniczych, ale też osiągnięcia w poprzednich miejscach pracy.

Ponadto powinno się zwiększyć jawność procesu konkursowego naboru. Po zakończeniu procedury naboru dokumentacja, $\mathrm{z}$ wyjątkiem danych podlegających ochronie, powinna być upubliczniana.

Spółki „córki” spółek skarbu państwa powinny być objęte takimi samymi zasadami, jakie obowiązują w spółkach „matkach”. Chodzi zarówno o zasady dotyczące jawności dokumentów, np. sprawozdań czy statutów, jak i sposobu naboru do ciał zarządczych. Obecnie to właśnie w spółkach córkach, obracających często ogromnymi kwotami i mających wpływ na duże fragmenty rynku, bez łamania prawa oraz jakiejkolwiek kontroli społecznej znajdują zatrudnienie nominaci partyjni.

Należy zdawać sobie jednak sprawę $\mathrm{z}$ tego, że nawet najlepsze rozwiązania systemowe i prawne nie zdadzą egzaminu, jeśli nie będzie wśród rządzących woli przestrzegania prawa i zasad konstytucyjnych. Wola ta jest osłabiana przez niską 
kulturę polityczną oraz świadomość, że poprzednicy ze względu na ich wcześniejsze zachowania czy zaniechania nie mają moralnego prawa domagania się innego stylu rządzenia.

\section{Bibliografia}

Afeltowicz, Ł. (2010). Zawłaszczone państwa, sieci społeczne i wyobraźnia socjologiczna. Krytyczna analiza koncepcji state capture. Studia Socjologiczne, nr 1: 69-105.

Burnetko, K. (2003). Stużba Cywilna w III RP: punkty krytyczne. Warszawa: Fundacja Batorego. http://www.batory.org.pl/ftp/program/przeciw-korupcji/publikacje/sluzba_cywilna.pdf

Celej, P. (2015). PiS przejmuje holding zbrojeniowy. W zarządzie firmy szef klubu „Gazety Polskiej" z Łomianek - nikt nie zna jego CV. Na Temat, 12.12.2015. http://natemat. pl/164931, pis-przejmuje-kluczowy-holding-zbrojeniowy-w-zarzadzie-firmy-szef-klubu-gazety-polskiej-bez-doswiadczenia

Dryszel, A. (2017). Co wolno wojewodzie. Rzeczpospolita, 28.09.2017.

Dziedziczak-Foltyn, A., Musiał, K. (2015). Dyskursy modernizacyjne i wielkie narracje rozwoju. Polska a kraje nordyckie. Przeglad Socjologiczny, nr 2(64): 9-43.

Ferfecki, W. (2017). Polska Agencja Kosmiczna w czarnej dziurze. Rzeczpospolita, 26.04.2017.

Fiskus i celnicy razem. Nie wszyscy mogą liczyć na pracę (2017). Dziennik Gazeta Prawna, 10.03.2017.

Gadowska, K. (2015). Dysfunkcje administracji. Stużba cywilna w perspektywie neoinstytucjonalnej. Kraków: Wydawnictwo UJ.

Gadowska, K. (2017). Praktyka obsadzania stanowisk w administracji skarbowej III RP w świetle wartości konstytucyjnych. Rocznik Lubuski, t. 43: 25-48.

Gadowska, K. (2018). Relacje między polityką i administracją w procesie tworzenia służby cywilnej w Polsce. Perspektywa nowego instytucjonalizmu. Zarzadzanie Publiczne Wydawnictwo Uniwersytetu Ekonomicznego, nr 1(43): 54-77.

Jasiecki. K. (2013). Kapitalizm po polsku. Między modernizacja a peryferiami Unii Europejskiej. Warszawa: IFiS PAN.

Jasiecki, K. (2016). Zasady merytokratyczne w polityce państwa - wzloty i upadki. Studia z Polityki Publicznej, nr 3(11): 9-40.

Komunikat PAP (2015). Rzeczpospolita, 9.12.2015. http://www.rp.pl/Przemysl-Obronny/ 312099804-Arkadiusz-Siwko-prezesem-Polskiej-Grupy-Zbrojeniowej.html\#ap-1

Zmiany w Polskiej Grupie Zbrojeniowej (2015). Komunikat rzecznika MON, 9.12.2015. http:// www.mon.gov.pl/aktualnosci/artykul/najnowsze/2015-12-09-zmiany-w-polskiej-grupie-zbrojeniowej/

Kopińska, G. (2018) Stanowiska publiczne jako łup polityczny. Warszawa: Forum Idei Fundacji im. Stefana Batorego. http://www.batory.org.pl/publikacje/artykuly_17/przeciw_korupcji_1

Kwiatkowski, M. (2017). Pułapki rewolucji kadrowej. Prakseologia, nr 159: 207-235. 
Paczocha, J. (2018). Partia w państwie, Raport Forum Obywatelskiego Rozwoju, Warszawa, luty 2018. https://for.org.pl/pl/raport-for-partia-w-panstwie-bezprecedensowa-wymiana-kadr-w-administracji-rzadowej-i-jej-legislacyjne-podstawy

Podstawy prawne działania Polskiej Agencji Kosmicznej (2017), 30.05.2017. http://pak.bip.gov.pl/ prawo-i-prace-legislacyjne/podstawy-prawne-dzialania-polskiej-agencji-kosmicznej.html

Sprawozdanie o stanie służby cywilnej i o realizacji zadań tej służby w 2016 roku (2017). Warszawa. https://dsc.kprm.gov.pl/aktualnosci/sprawozdanie-szefa-sluzby-cywilnej-za-2016-rok: 20-21, 29-31, wykresy 2, 3, 7.

Statut spółki Polska Grupa Zbrojeniowa spółka Akcyjna (2018). http://pgzsa.pl/

Tylko prezes Jagieło śpi spokojnie (2016). Rzeczpospolita, 14.04.2016.

Wojnarska-Krajewska, E. (2006). Opinia prawno-porównawcza do projektu ustawy o służbie cywilnej (druk nr 552) oraz projektu ustawy o państwowym zasobie kadrowym, obsadzaniu wysokich stanowisk państwowych oraz o zmianie niektórych ustaw (druk nr 553), z 2006 roku, w którym cytowano: R. Herbut, Administracja publiczna - modele, funkcja i struktura, w: Administracja i polityka, A. Ferens, I. Macek (red.). Wrocław 1999: 48.

Wójcik, K. (2017). Po raz pierwszy ubyło urzędników mianowanych. Rzeczpospolita, 6.04.2017.

Zmiany w zarządach spółek Polskiej Grupy Zbrojeniowej (2016), komunikat PGZ z 21.09.2016. http://pgzsa.pl/a/285, zmiany-w-zarzadach-spolek-polskiej-grupy-zbrojeniowej

Zybała, A. (2017). Public administration reforms in Poland, w: J. Nemec, D. Špaček, 25 Years of Public Administration Developments and Reforms in V4 region. Brno: 84-114.

Zybertowicz, A. (2013). III RP. Kulisy systemu. Warszawa: Wydawnictwo Słowa i Myśli.

\section{Akty prawne}

Projekt ustawy o zmianie ustawy - Prawo ochrony środowiska, druk nr 1127,

http://orka.sejm.gov.pl/Druki8ka.nsf/0/B3EFC2F7BF0315DEC1258087005ACF95/\%24File/1127. pdf

Projekt ustawy o zmianie ustawy - Prawo ochrony środowiska, druk nr 1661 z 16.06.2017, http://www.sejm.gov.pl/Sejm8.nsf/PrzebiegProc.xsp?nr=1661

Ustawa z dnia 27 kwietnia 2001 r. - Prawo ochrony środowiska, Dz. U. 2001, nr 62 poz. 627, art. 400 ust. 2.

Ustawa z dnia 27 kwietnia 2001 r. - Prawo ochrony środowiska w wersji sprzed nowelizacji, Dz. U. 2001, nr 62, poz. 627, art. 400 fust. 2 pkt 5.

Ustawa z dnia 30 grudnia 2015 r. o zmianie ustawy o radiofonii i telewizji, Dz. U. 2016, poz. 25.

Ustawa z dnia 30 grudnia 2015 r. o zmianie ustawy o służbie cywilnej oraz niektórych innych ustaw, Dz. U. 2016, poz. 34.

Ustawa z dnia 22 czerwca 2016 r. o Radzie Mediów Narodowych, Dz. U. 2016, poz. 929.

Ustawa z dnia 16 grudnia 2016 o zasadach zarządzania mieniem państwowym, Dz. U. 2016, poz. 2259, art. 22. 